\title{
1 Effect of fly ash on the service life, carbon footprint and embodied energy \\ 2 of high strength concrete in marine environment
}

3 Pradip Nath, Prabir K. Sarker and Wahidul K. Biswas*

4 School of Civil and Mechanical Engineering, Curtin University, Australia

5

6 ABSTRACT

7 Durability is one of the primary considerations in designing concrete structures in aggressive

8 environment. This paper presents a study of concretes containing fly ash as $30 \%$ and $40 \%$ of

9 the total binder in regards to service life, carbon footprint and embodied energy. A simple deterministic service life estimation technique using the well-known Fick's law was applied to assess the service life of similar grade concrete mixes against the corrosion due to chloride diffusion. The parameters needed to predict the service life of concrete were determined from laboratory experiments. Compared to control concrete, fly ash concretes showed less chloride diffusion which is considered as the dominant form of attack in reinforced concrete structures in marine environment and thus the latter is more durable or have longer service life than the former. Finally, this paper presents the application of life cycle assessment to measure carbon footprint and embodied energy consumption saving benefits of the use of more durable fly ash concretes in the aggressive marine environment.

Keywords: Fly ash concrete, marine environment, durability, carbon footprint, embodied energy consumption

\footnotetext{
${ }^{*}$ Corresponding author.

E-mail address: $\underline{w . b i s w a s @ c u r t i n . e d u . a u ~(W . K . ~ B i s w a s), ~}$
} 


\section{Introduction}

The most common binder of traditional concrete is Portland cement. Cement production needs high temperature calcination which is an energy intensive process and causes approximately $5-7 \%$ of man-made $\mathrm{CO}_{2}$ emissions globally $[1,2]$. The global cement production is expected to increase from 3.27 billion metric tons in 2010 to 4.83 billion metric tons in 2030 [3]. Such increase in cement production will significantly increase the amount of $\mathrm{CO}_{2}$ emissions in the atmosphere to cause global warming impacts. One effective way to reduce these emissions of concrete production is to partially replace cement by industrial by-products with pozzolanic property.

Fly ash is produced as a by-product in coal-fired power plants and it is a pozzolanic material. When mixed with Portland cement, the products of fly ash-cement interaction are very similar to those formed by cement hydration [4]. Incorporation of fly ash in partial replacement of cement shows reliable mechanical and durability properties [5]. In the context of environmental sustainability, partial replacement of cement with fly ash in concrete can be an effective way of reducing overall cement production, which in turn will reduce GHG emissions, energy consumption and solid wastes. However, the usage of fly ash by concrete industries is still limited. According to Ash Development Association of Australia (ADAA) [6], in 2015, surplus amount of fly ash constituting about $81 \%$ of total generation (12.1 million tonne) is awaiting some future opportunity for economic reuse. Increased utilisation of fly ash in concrete can help improve the economic and environmental performance of concrete manufacturing.

Service life of concrete structures mainly depends on the durability of concrete. Concrete made of traditional Portland cement is considered as a durable material for the non-aggressive environment. However, being a heterogeneous porous material, concrete is susceptible to 
degradation in aggressive exposures such as in marine environment, underground and in exposure to chemicals $[7,8]$. In such conditions, concrete suffers early deterioration which eventually reduces service life of structures and require expensive repair and maintenance. For instance, in USA approximately 18 to 21 billion dollars is spent every year for repairing, rehabilitation, strengthening and protection of the concrete structures [9]. Nonetheless, good resistance against aggressive exposures can be achieved by choice of materials and their proper proportioning without increasing the cost of concrete production and further maintenance [10].

The use of fly ash as a partial replacement of cement in concrete has been reported to provide enhanced resistance to chloride penetration in marine environment [11-15]. The use of fly ash with cement can improve the durability of concrete by its pozzolanic reaction and particle packing effects [16]. However, the level of effectiveness of fly ash depends on its type, dosage and appropriate mix proportioning of concrete. Thus this research has studied the implication of the use of fly ash as a partial substitution of cement on the service life of reinforced concrete structures in marine environment and its associated environmental impacts. The results of this study will be useful for designing durable concrete for structures in marine (e.g. seaport buildings) and desalination projects.

For quantifying the environmental implications of the use of FA in concrete, GHG emissions and embodied energy consumption indicators have been considered in this research as the construction industries are responsible for almost 23\% [17] of Australia's annual GHG emissions and approximately $20 \%$ of the total energy consumption $[18,19]$..

Life Cycle Assessment (LCA) is an environmental management tool that has been widely used to estimate GHG emissions and embodied energy consumption of building industries [20]. This tool captures the overall environmental impacts of a product, process or services from mining, production, assembly, operation, to end of life [21].This paper uses the LCA method to estimate life cycle GHG emissions causing global warming impact (or carbon footprint) and 
embodied energy consumption of concrete made of cement and fly ash for use in the marine environment $[22,23]$ and to identify further environmental improvement opportunities to design low carbon infrastructure (i.e. the infrastructure which is specifically designed to achieve reduced level of life cycle GHG and embodied energy consumption) [20]. Firstly, fly ash concrete specimens were cast and tested in the laboratory in order to determine the durability properties for prediction of service life. Then these laboratory results including service life, compositions and energy and chemical inputs of concrete manufacturing for with and without FA were incorporated into the LCA analysis for estimating carbon footprint and embodied energy consumption.

\section{Techno-environmental assessment of fly ash concrete}

\subsection{Materials}

Concrete specimens were cast in the laboratory using commercially available materials. A General Purpose (GP) Portland cement conforming to Australian standard [24] was used as the main binder and a Class F fly ash [25] was used to partially replace cement. The fine aggregate was natural sand with a nominal maximum size of $1.18 \mathrm{~mm}$ and the coarse aggregate was crushed granite with nominal maximum size of 7, 10 and $20 \mathrm{~mm}$. Both types of aggregates met the Australian standard [26]. Normal tap water was used in the mixing and a high range water reducer (superplasticiser) was used to enhance workability of the concrete.

\subsection{Mix design and casting of specimens}

The mix design of concrete was conducted using the ACI 211.4R-08 guidelines [27] of the American Concrete Institute (ACI). A control concrete mixture without any fly ash (FA0), a mixture with $30 \%$ fly ash (FA30) and a mixture with $40 \%$ fly ash (FA40) were used to cast test specimens and to determine the strength and durability properties. The mixtures were designed 
107

108

109

110

111

112

113

114

115

116

117

with varying total binder content and water-binder ratio $(\mathrm{w} / \mathrm{b})$ in order to achieve similar 28day compressive strengths. The dosage of superplasticiser was adjusted to achieve adequate workability of the fresh concrete. The mixture proportions and the measured slumps of the concretes are given in Table 1.

It can be seen from the slump values in Table 1 that the inclusion of fly ash improved the workability of concrete. Increase in fly ash generally allowed reduction of w/b ratio to achieve the similar workability. Concrete cylinders of $100 \mathrm{~mm}$ diameter and $200 \mathrm{~mm}$ height were cast for compressive strength and chloride diffusion test. The cylinders were demoulded at 24 hours after casting and then cured in water at $23{ }^{\circ} \mathrm{C}$ for up to 28 days.

\section{Table 1}

Concrete mixture proportions and slump

\begin{tabular}{|c|c|c|c|c|c|c|c|c|c|}
\hline \multirow[b]{2}{*}{$\begin{array}{l}\text { Mix } \\
\text { ID }\end{array}$} & \multicolumn{3}{|c|}{ Binder } & \multicolumn{2}{|c|}{ Aggregate } & \multirow[b]{2}{*}{$\begin{array}{c}\text { Water } \\
\left(\mathrm{kg} / \mathrm{m}^{3}\right)\end{array}$} & \multirow[b]{2}{*}{$\begin{array}{c}\text { Plasticiser } \\
\left(\mathrm{kg} / \mathrm{m}^{3}\right)\end{array}$} & \multirow[b]{2}{*}{$\mathrm{w} / \mathrm{b}$} & \multirow[b]{2}{*}{$\begin{array}{l}\text { Slump } \\
(\mathrm{mm})\end{array}$} \\
\hline & $\begin{array}{c}\text { Fly ash } \\
(\%)\end{array}$ & $\begin{array}{c}\text { Fly ash } \\
\left(\mathrm{kg} / \mathrm{m}^{3}\right)\end{array}$ & $\begin{array}{c}\text { Cement } \\
\left(\mathrm{kg} / \mathrm{m}^{3}\right)\end{array}$ & $\begin{array}{l}\text { Granite } \\
\left(\mathrm{kg} / \mathrm{m}^{3}\right)\end{array}$ & $\begin{array}{c}\text { Sand } \\
\left(\mathrm{kg} / \mathrm{m}^{3}\right)\end{array}$ & & & & \\
\hline FA0 & 0 & 0 & 355 & 1185 & 740 & 145.5 & 5.11 & 0.41 & 140 \\
\hline FA30 & 30 & 132 & 308 & 1185 & 661 & 141.0 & 4.77 & 0.32 & 170 \\
\hline FA40 & 40 & 176 & 264 & 1185 & 665 & 136.5 & 4.75 & 0.31 & 185 \\
\hline
\end{tabular}

\subsection{Test methods}

\subsubsection{Compressive strength}

The compressive strength was evaluated by tests performed on the cylindrical specimens $(100 \times 200 \mathrm{~mm})$ at the ages of $3,7,28,56,91,210$ and 335 days.

\subsubsection{Chloride diffusion}

Chloride diffusion test was carried out in accordance with the NT Build 443 test method [28]. Three slices of the 28-day sample were used for the chloride diffusion test and one other 
slice was used to determine the initial chloride content. The samples were $50 \mathrm{~mm}$ thick and $100 \mathrm{~mm}$ in diameter. The test specimens were epoxy-coated on every face leaving only one surface open to be exposed to the sodium chloride solution $(165 \pm 1 \mathrm{gm} / \mathrm{L})$. The exposure period was extended up to 56 days considering the presence of fly ash, low water to binder ratio and the maturity of the concrete. After that, eight layers were grinded from each sample at an interval of $2 \mathrm{~mm}$ from the exposed surface and dried in the oven. A potentiometric titration method was used to determine the acid soluble chloride content of the oven-dried ground samples. The chloride content in each layer was calculated as the average of the test results from three identical samples. The values of surface chloride concentration $\left(C_{s}\right)$ and apparent chloride diffusion coefficient $\left(D_{a}\right)$ were determined by fitting Eq. 1 to the measured chloride contents by means of a non-linear regression analysis in accordance with the method of least squares fit [28]. Equation 1 is a solution of Fick's $2^{\text {nd }}$ law of diffusion which represent the chloride ion penetration into concrete [29].

$$
C(x, t)=C_{s}-\left(C_{s}-C_{i}\right) \cdot \operatorname{erf}\left[\frac{x}{\sqrt{4 \cdot D_{a} \cdot t}}\right]
$$

Where, $C(x, t)=$ chloride concentration measured at depth $x$ and exposure time $t$ (mass \%), $C_{s}=$ projected chloride concentration at the interface between the exposure liquid and test surface $(\operatorname{mass} \%), C_{i}=$ initial chloride concentration in concrete prior to submersion in the exposure solution (mass \%), $x=$ depth below the exposed surface $(\mathrm{m}), D_{a}=$ apparent chloride diffusion coefficient $\left(\mathrm{m}^{2} / \mathrm{s}\right), t=$ the exposure time (seconds) and $e r f=$ error function.

\subsection{Service life estimation}

For calculating service life against chloride attack, a deterministic approach based on Fick's $2^{\text {nd }}$ law of diffusion was used which has been widely applied and recommended by previous 
researcher [29]. A practical procedure described by Cao and Bucea [30] for service life

Equations 2 to 4 were applied in this study to predict $D_{a}$ at time $t$ using $D_{a}$ at 28 days from the experimental results $[31,32]$.

$$
D_{a}(t)=D_{28} \cdot\left(\frac{28}{t}\right)^{m}+D_{u l t} \cdot\left(1-\left(\frac{28}{t}\right)^{m}\right)
$$

$$
\begin{aligned}
& D_{u l t}=D_{28} \cdot\left(\frac{28}{36500}\right)^{m} \\
& m=0.26+0.4\left(\frac{F A}{50}+\frac{S G}{70}\right)
\end{aligned}
$$

Where, $D_{a}(t)=$ chloride diffusion coefficient $\left(\mathrm{m}^{2} / \mathrm{s}\right)$ at time $t$ (days), $D_{28}=$ chloride diffusion coefficient at 28 days $\left(\mathrm{m}^{2} / \mathrm{s}\right), D_{u l t}=$ ultimate chloride diffusion coefficient $\left(\mathrm{m}^{2} / \mathrm{s}\right)($ Eq. 3$), m=$ diffusion decay constant (Eq. 4), $F A=$ percentage of fly ash and $S G=$ percentage of slag in the binder.

The value of $m$ varies in the range of 0.26 - 0.60 depending on the presence of supplementary cementitious materials in the mix [32]. While the value of $m$ equals to 0.26 was used for control concrete as per Eq. 4, a conservative value of $m=0.40$ was used for fly ash concretes considering the variations of cementitious mixes of this study from the original mixes used in order to develop Equations 2 to 4 . The value of $C_{s}$ was used as $0.8 \%$ for both fly ash concrete and control concrete which is suggested by Cao and Bucea [30] for the grade 60 concretes. These values of $D_{a}(t)$ and $C_{s}$ as well as $C_{i}$ that obtained from experiments, were substituted in Eq. 1 to calculate chloride concentration at the cover depth of reinforcement $(x)$. Corrosion of the reinforcing steel is considered to be initiated by the chloride concentration reaching a threshold level $\left(C_{c r}\right)$ at the cover depth of reinforcement. There is no universally accepted single 
value of $C_{c r}$ for corrosion initiation. The value of $C_{c r}$ is equal to $0.1 \%$ and $0.2 \% \mathrm{w} / \mathrm{w}$ of concrete, 167 as suggested by Cao and Bucea [30], were used in this study. The calculation was repeated with different sets of $D_{a}(t)$ and $t$ until the concentration at cover depth became equal to the assumed critical chloride level $\left(C(\right.$ cover,$\left.t)=C_{c r}\right)$. The time at this point is the estimated service life of the concrete. In this study, age at initiation of corrosion of the reinforcing steel is being considered as the service life of the concrete, by taking into account the uncertainty of subsequent corrosion rate and serviceability of the structure [32, 33]. Service life was calculated for varying concrete cover depths ranging from 10 to $100 \mathrm{~mm}$.

\subsection{Quantification of environmental impacts}

The LCA has been used to quantify carbon footprint and embodied energy consumption of the concrete mixtures following the guidelines as outlined in ISO14040-44 [21] which consists of four steps, namely: goal and scope, inventory analysis, impact assessment and interpretation.

The goal of this study is to assess the carbon footprint and embodied energy consumption of the production and use of concrete. Three concrete mixes, as given in Table 1, were considered for LCA analysis: a control concrete without any fly ash (FA0), a concrete with $30 \%$ fly ash (FA30) and a concrete with $40 \%$ fly ash (FA40).

The system boundary of this concrete LCA includes the mining to use stages of the product life cycle. This consists of several stages including mining of raw material, manufacturing and processing of construction materials, transportation of these materials to the construction site, construction stage, and usage stage. The disposal/recycling strategy of concrete has been excluded as it is uncertain what will happen at the end of life of these products. 
The functional unit of this study is $1 \mathrm{~m}^{3}$ of concrete used over its service life. Since the service lives of these three concrete mixes vary, their environmental performance has been compared per $\mathrm{m}^{3}$ per year basis.

An inventory analysis was conducted to estimate energy and materials used during concrete life cycle. The amount of different materials or compositions of concrete mixtures and their service lives were based on the experimental data measured following the procedure in the previous section. These inputs and outputs are used to create the life cycle inventory (LCI)

which were pre-requisites to carry out a life cycle impact analysis. represent the local conditions of Western Australia (WA). Firstly, the inputs of each concrete class are multiplied by the corresponding emission factors available in the emission databases to estimate their environmental impacts and then these impacts are added to determine the overall impact. Where local emission databases were not available, new libraries were developed from similar LCA studies. Australian emission databases have been considered for cement, fly ash, sand, electricity, transportation and water [35]. The unit of tkm (tonnekilometres) was used in order to calculate the transport emissions. Since the databases for coarse aggregate are not available in the SimaPro software databases, new databases for them were created knowing the diesel consumption for crushing them. The emissions associated with the combustion of diesel are available in the Australian databases. The foreign database, which is known as Eco-invent, has only been used for determining the emissions from the production of plasticiser [36]. 

(GWP) method was used to calculate the associated global warming potential (GWP) or carbon footprint of three concrete mixes [37]. GWP or carbon footprint values are expressed over 20, 100- and 500-year time horizons to assist policy makers in the relevant climate change decisions. The greenhouse gases (e.g. $\mathrm{CO}_{2}, \mathrm{CH}_{4}$ and $\mathrm{N}_{2} \mathrm{O}$ ) associate with the production and use of inputs were converted to $\mathrm{CO}_{2}$-equivlanet (or $\mathrm{CO}_{2}$ e-) using established conversion factors for time horizons of 20-, 100- and 500-year (IPCC 2013). But we only used 100-year horizon for converting $\mathrm{GHG}$ emissions to $\mathrm{CO}_{2} \mathrm{e}$ - as it is considered as the reference for climate change policy $[38,39]$. The cumulative energy demand method was also used to estimate the embodied energy consumption of these products.

The inputs used during the life cycle of concrete have been converted to carbon dioxide-

Using Eq. (6), all inputs in the LCI have been multiplied by the corresponding energy consumption values to determine the total embodied energy consumption of concrete [40]. 
where, $E_{i}$ is the embodied energy consumption of an input $i$.

238 There are uncertainties associated with the quality of data (i.e. inputs and output and the emission factors) that is used for estimating GHG emissions (GWP or carbon footprint) and 240 embodied energy consumption. In order to estimate these uncertainties a stochastic modelling 241 approach, [41], known as Monte Carlo Simulation (MCS) was conducted to estimate the 242 uncertainty of each of these data points and predict the influence that a variable has on the 243 environmental impacts [42]. The simulation is an iterative approach which utilizes an input 244 from a probability distribution and produces a distribution of all possible values for 1000 245 iterations and 95\% confidence level [42]. 


\section{Table 2}

248 Life cycle inventory of concrete mixtures

\begin{tabular}{|c|c|c|c|c|c|c|c|}
\hline \multirow{2}{*}{$\begin{array}{l}\text { Stage } 1-\text { Mining to material } \\
\text { Ingredients }\end{array}$} & \multirow[b]{2}{*}{ FA0 } & \multirow[b]{2}{*}{ FA30 } & \multirow[b]{2}{*}{ FA40 } & \multicolumn{4}{|c|}{ Stage 2 -transportation of materials to batching plant } \\
\hline & & & & & FA0 & FA30 & FA40 \\
\hline Fly ash $(\%)$ & 0 & 30 & 40 & $\mathrm{~km}$ travelled & $\mathrm{tkm} / \mathrm{m}^{3}$ & $\mathrm{tkm} / \mathrm{m}^{3}$ & $\mathrm{tkm} / \mathrm{m}^{3}$ \\
\hline Cement $\left(\mathrm{kg} / \mathrm{m}^{3}\right)$ & 355 & 308 & 264 & 10 & 3.55 & 3.08 & 2.64 \\
\hline Fly Ash $\left(\mathrm{kg} / \mathrm{m}^{3}\right)$ & 0 & 132 & 176 & 191 & 0 & 25.21 & 33.62 \\
\hline Coarse aggregate $-20 \mathrm{~mm}\left(\mathrm{~kg} / \mathrm{m}^{3}\right)$ & 746 & 746 & 746 & 12 & 8.95 & 8.95 & 8.95 \\
\hline Coarse aggregate $-10 \mathrm{~mm}\left(\mathrm{~kg} / \mathrm{m}^{3}\right)$ & 166 & 166 & 166 & 12 & 1.99 & 1.99 & 1.99 \\
\hline Coarse aggregate - $7 \mathrm{~mm}\left(\mathrm{~kg} / \mathrm{m}^{3}\right)$ & 273 & 273 & 273 & 12 & 3.28 & 3.28 & 3.28 \\
\hline Sand $\left(\mathrm{kg} / \mathrm{m}^{3}\right)$ & 740 & 661 & 665 & 20 & 14.8 & 13.22 & 13.30 \\
\hline Water $\left(\mathrm{kg} / \mathrm{m}^{3}\right)$ & 145.5 & 141 & 136.5 & - & - & - & - \\
\hline Superplasticiser $\left(\mathrm{kg} / \mathrm{m}^{3}\right)$ & 5.11 & 4.77 & 4.75 & - & - & - & - \\
\hline Total $\mathrm{kg} / \mathrm{m}^{3}$ & 2430.61 & 2431.77 & 2431.25 & Total $\mathrm{tkm} / \mathrm{m}^{3}$ & 32.57 & 55.732 & 63.776 \\
\hline \multicolumn{8}{|l|}{ Stage 3-Manufacturing at batching plant } \\
\hline $\begin{array}{l}\text { Energy consumption at the batching plant } \\
\left(\mathrm{kWh} / \mathrm{m}^{3}\right)\end{array}$ & 76.89 & 78.09 & 78.56 & & & & \\
\hline \multicolumn{8}{|c|}{ Stage 4 - Transportation from batching plant to point of use } \\
\hline Amount of concrete transported (Excl. water) & 2284.27 & 2319.97 & 2333.96 & & & & \\
\hline $\mathrm{tkm}$ & 7.69 & 7.81 & 7.86 & & & & \\
\hline
\end{tabular}




\section{Results and discussion}

251

252

253

254

255

256

257

258

259

260

261

262

263

264

\subsection{Structural analysis of concrete mixtures}

\subsubsection{Compressive strength}

Compressive strength is used as the primary design consideration of concrete. Design of concrete structures is usually conducted based on the 28-day compressive strength of concrete. The development of compressive strength of the concrete mixes at different ages up to 335 days is plotted in Fig. 1. As shown in Table 3, the 28-day compressive strengths of the mixtures FA0, FA30 and FA40 were $69 \mathrm{MPa}, 73 \mathrm{MPa}$ and $66 \mathrm{MPa}$, respectively. These strengths are above $50 \mathrm{MPa}$, which is the minimum required compressive strength of concrete for maritime structures in the spray and splash zones as recommended by the Australian Standard (AS 3600, 2009) [43]. It can be seen from Fig. 1 that the strength development rates of the fly ash concretes were higher than that of the control concrete during the age between 7 days and 56 days. The fly ash concretes gained more than $110 \%$ strength of the control concrete at 56 days and then continued to gain strength at slower rates. The late age strength development is attributed to the well-known pozzolanic reaction of fly ash [44].

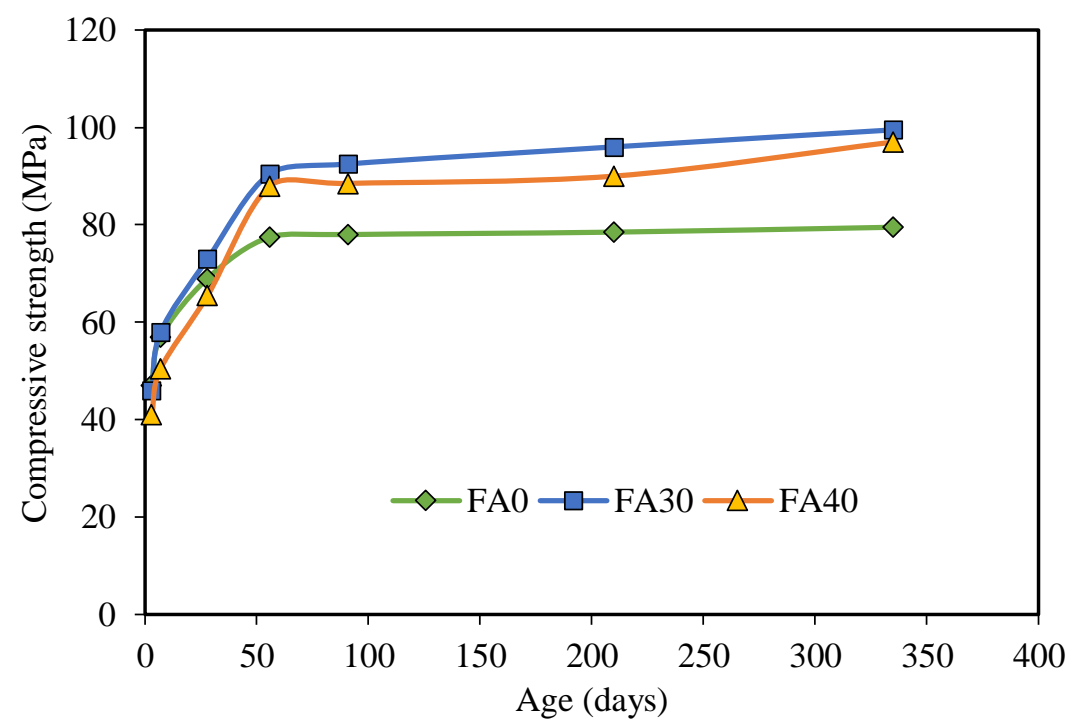

Fig 1. Compressive strength development of concrete mixtures. 
Table 3

269 Compressive strength and chloride diffusion results of concrete

\begin{tabular}{|c|c|c|c|c|c|}
\hline \multirow[b]{2}{*}{ Mix ID } & \multicolumn{3}{|c|}{28 days } & \multicolumn{2}{|c|}{180 days } \\
\hline & $\begin{array}{l}\text { Compressive } \\
\text { strength } \\
\text { (MPa) }\end{array}$ & $\begin{array}{c}\text { Cl diffusion } \\
\text { coefficient, } D_{a} \\
\left(\times 10^{-12} \mathrm{~m}^{2} / \mathrm{s}\right)\end{array}$ & $\begin{array}{c}\text { Surface } \\
\text { chloride (mass } \\
\% \text { of concrete) }\end{array}$ & $\begin{array}{l}\text { Cl diffusion } \\
\text { coefficient, } D_{a} \\
\left(\times 10^{-12} \mathrm{~m}^{2} / \mathrm{s}\right)\end{array}$ & $\begin{array}{c}\text { Surface } \\
\text { chloride (mass } \\
\text { \% of concrete) }\end{array}$ \\
\hline FA0 & 69 & 4.68 & 0.57 & 3.41 & 0.62 \\
\hline FA30 & 73 & 3.51 & 0.37 & 0.70 & 1.38 \\
\hline FA40 & 66 & 3.42 & 0.40 & 0.90 & 1.05 \\
\hline
\end{tabular}

270

\subsubsection{Chloride diffusion}

272

The concrete samples were exposed to $\mathrm{NaCl}$ solution at the age of 28 days and 180 days.

The results of chloride diffusion test after 56 days of exposure in submerged condition are given in Table 3. The variations in diffusion coefficients of the concrete samples are shown in

Fig. 2. It can be seen from the results that, fly ash concretes have shown greater resistance to chloride diffusion as compared to the control concrete. The chloride diffusion coefficients of the concretes with no fly ash, $30 \%$ fly ash and $40 \%$ fly ash were $4.68 \times 10^{-12} \mathrm{~m}^{2} / \mathrm{s}, 3.51 \times 10^{-12}$ $\mathrm{m}^{2} / \mathrm{s}$ and $3.42 \times 10^{-12} \mathrm{~m}^{2} / \mathrm{s}$, respectively for 28 -day samples. The reductions of chloride diffusions by fly ash are consistent with the reduction of permeability of these mixtures, as presented previously [45]. The product of pozzolanic reaction and the filling effect of fine unreacted fly ash particles, together with the lower water to binder ratio resulted in a denser microstructure that eventually reduced the chloride penetration of the fly ash concretes. The chloride diffusion decreased with the increase of age from 28 days to 180 days for all the three mixtures. This is due to the continued hydration of the binder with the increase of age. However, the reduction of the chloride diffusion coefficient with age was much higher in the 
fly ash concretes than in the control concrete. The inclusion of fly ash reduced chloride

287 diffusion coefficient of the concrete mixtures by at least $25 \%$ and $73 \%$ of the control concrete's value at 28 days and 180 days of age, respectively. The significantly higher resistance to chloride penetration of the fly ash concretes is due to the continued pozzolanic reaction of the fly ash at later ages.

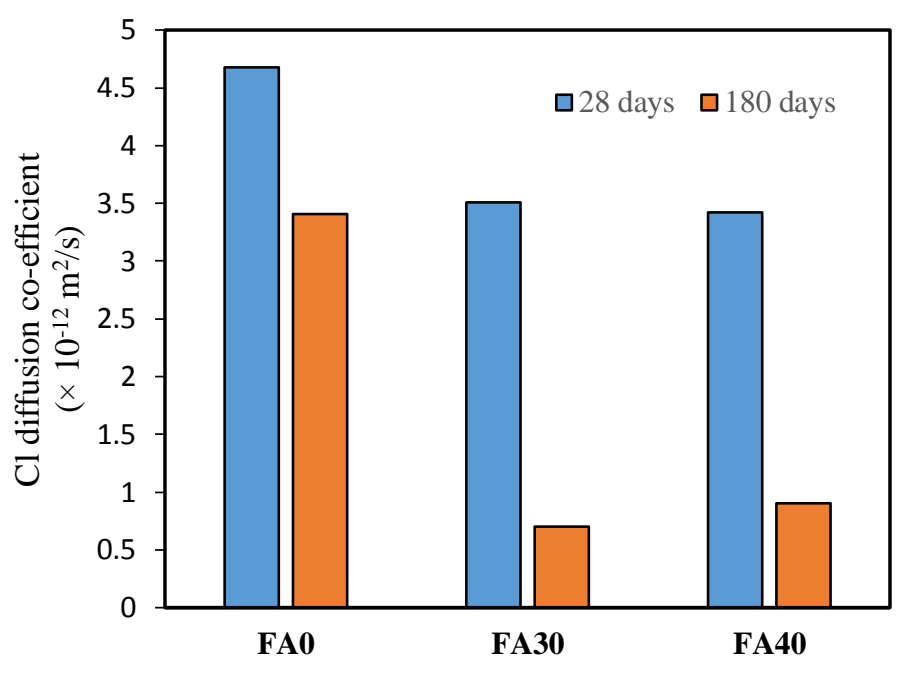

Fig 2. Comparison of chloride diffusions of concrete mixes at different ages.

The surface chloride concentration $\left(C_{s}\right)$ over the period of exposure is an important parameter related to chloride diffusion. Usually at maturity, fly ash concretes accrue higher surface chloride concentration than control concrete due to their higher resistance to chloride diffusion [46]. It can be seen from Table 3 that, at 28 days, fly ash concretes had less amount of surface chloride concentration as compared to that of the control concrete. This is due to the early age effect of Class F fly ash. The test was conducted at 28 days when fly ash concretes continued to develop its mechanical properties through pozzolanic reactions, as evident in the compressive strength results. However, at 180 days, fly ash concretes accrued higher surface chloride than the control concrete. This is because of the increased resistance to chloride penetration by the inclusion of fly ash in the mixtures. 


\subsubsection{Service life}

The method described in Section 2.4 was used to predict the service life of reinforced concrete based on the 28-day chloride diffusion test results. Despite the fact that, the hydration of fly ash concrete continued beyond 28 days, it was conservatively assumed that fly ash concretes had reached the similar maturity of the control concrete at 28 days, as the mixtures achieved similar 28-day strengths.

(a)

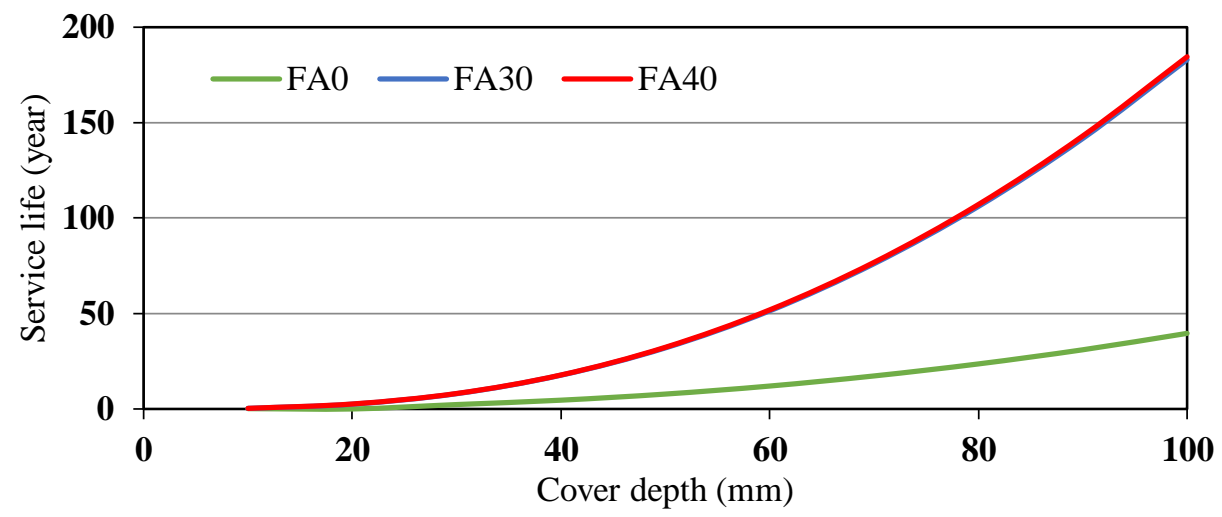

(b)

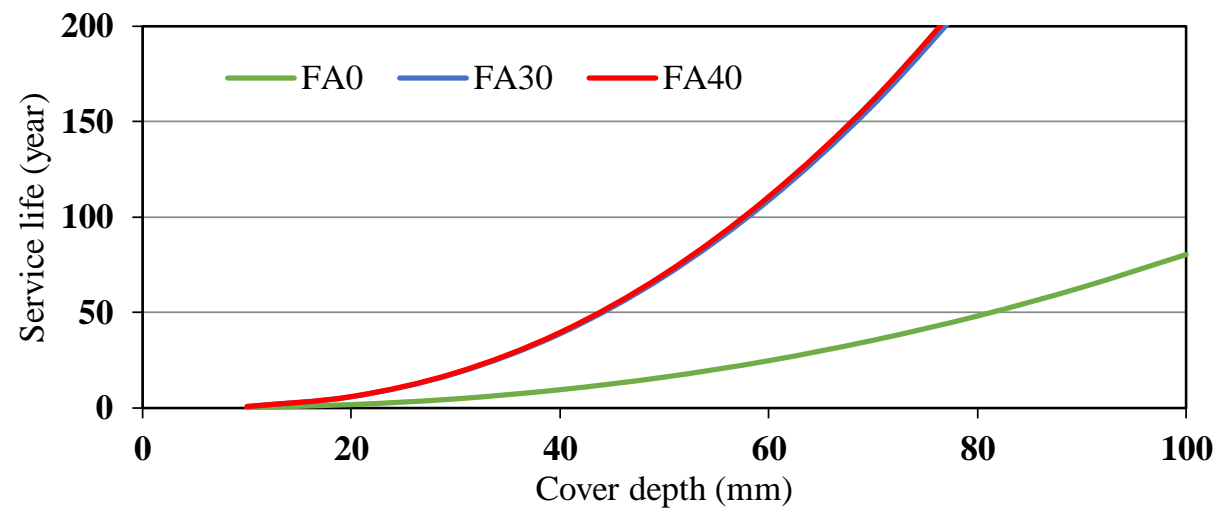

Fig 3: Variation of service life with cover depth when (a) $\mathrm{C}_{\mathrm{cr}}=0.1 \%$ (b) $\mathrm{C}_{\mathrm{cr}}=0.2 \%$

The service lives of reinforced concrete for various cover depths were predicted as plotted in Fig. 3. The graphs present the variations of service life of similar grade concretes having different mixture proportions with the assumptions outlined in section 2.4. It can be seen from the figures that, the service life of the fly ash concretes is much longer than the control concrete 
for the same concrete cover to the reinforcing steel. There is no significant difference between the results of the concretes with $30 \%$ and $40 \%$ fly ash, since the difference between the experimental values of the 28-day diffusion coefficients of the two fly ash concretes was very small and the same value of diffusion decay constant $m$ was used in the calculation for mixtures FA30 and FA40.

The effect of critical chloride level $\left(C_{c r}\right)$ on the cover depth requirement is compared in Fig. of $C_{c r}$ for any given cover depth. In other words, concrete with higher $C_{c r}$ requires less cover depth for a given service life. When the value of $C_{c r}$ is raised from $0.1 \%$ to $0.2 \%$ of concrete ( $100 \%$ increase), the required cover depth decreased by $25 \%$. Since there is no universal value of $C_{c r}$, the lower value can be suggested for design conservatively.

\section{Table 4}

Cover depth requirement for the service life of 50 and 100 years

\begin{tabular}{c|c|cc|cc}
\hline \multirow{2}{*}{ Mix ID } & \multirow{2}{*}{$\begin{array}{c}\text { Fly ash } \\
(\%)\end{array}$} & \multicolumn{2}{|c|}{$\begin{array}{c}\text { Required cover depth }(\mathrm{mm}) \\
\text { when } C_{c r}=0.1 \%\end{array}$} & \multicolumn{2}{c}{$\begin{array}{c}\text { Required cover depth }(\mathrm{mm}) \\
\text { when } C_{c r}=0.2 \%\end{array}$} \\
\cline { 3 - 6 } & & 50 years & 100 years & 50 years & 100 years \\
\hline FA0 & 0 & 110 & 150 & 82 & 110 \\
FA30 or, FA40 & 30 or, 40 & 60 & 78 & 44 & 58 \\
\hline
\end{tabular}

The cover depth requirement for fly ash concretes to achieve expected service life of 50 years and 100 years are predicted (Table 4). For the assumed conditions, the fly ash concretes required only $52-55 \%$ of cover depth of control concrete for service life up to 100 years. This indicates that, fly ash concretes having similar 28-day strength of control concrete required less (at least 45\%) cover depth to achieve similar service life of control concrete. As illustrated in Table 4, service life can be increased from 50 years to 100 years by increasing the cover as much as $30-32 \%$ for fly ash concrete and $34-36 \%$ for the control concrete. 
Service life estimation of this study has been compared with those predicted by Thomas [47], Chalee at al. [13] and Shafiq [48]. Whilst the prediction models of these studies were based on different threshold chloride values and concrete mixture proportions, their results differ slightly from those of the current study. The time to initiate corrosion in reinforcing steel with $50 \mathrm{~mm}$ cover depth was approximately 7,8 and 8 years for cement concrete and 30, 24 and 32 years for fly ash concrete as predicted by Thomas [47], Chalee at al. [13] and the current study $(\mathrm{Ccr}=0.1 \%)$, respectively. However the prediction of corrosion initiation time of the same specimen by Shafiq [48] was found to be 25 years longer than the aforementioned studies. The difference is due to consideration of different diffusion coefficients and threshold chloride values. Nevertheless, results of all these studies confirm that the service life of a concrete product can be enhanced by replacing cement with FA.

According to the Australian Standard AS 3600-2009 [43], for a design life of 50 years \pm $20 \%$, the required cover depth is $35 \mathrm{~mm}$ for permanently submerged condition (exposure classification B2) where standard formwork and compaction are used. This value is significantly less than that estimated for 50 years of service life of both the fly ash concretes and the control concrete. In this regard, it should be noted that in this study the variation of diffusion coefficient for the presence of fly ash in concrete was considered in terms of diffusion coefficient at 28 days and the diffusion decay constant $(m)$. The variation of service life due to the variation of other variables, such as $C_{s}, C_{c r}$ and cover depth, over the age [33] was not considered in this estimation. Moreover, the critical chloride content is assumed constant for all the concretes, which can be different for fly ash concretes [49]. However, the estimates presented here show the effects of fly ash on service life of reinforced concrete based on the 28-days chloride diffusion values. 
The use of fly ash as a partial replacement of energy and carbon intensive cement has thus been found to increase the durability of concrete in the marine environment. This means that more virgin resources like limestone and iron for steel production can potentially be conserved and the environmental impacts associated with the production of cement can be avoided. In addition, inclusion of fly ash in concrete could potentially improve the green star rating of concrete structures which is a very important design consideration for the development of buildings and infrastructures in Australia [50].

Using an LCA methodology, as outlined in Section 2.5, carbon footprint and embodied energy consumption of the concrete mixtures FA0, FA30 and FA40 have been determined to estimate the environmental benefits associated with the replacement of cement with fly ash iterations using the SimaPro software. The mean values of carbon footprint of $1 \mathrm{~m}^{3}$ of FA0, FA30 and FA40 concretes have been estimated to be $345 \mathrm{~kg} \mathrm{CO}_{2}$ e-, $269 \mathrm{~kg} \mathrm{CO}_{2}$ e- and 269 $\mathrm{kg} \mathrm{CO}_{2}$ e-, respectively. In the case of embodied energy consumption, the values are $3090 \mathrm{MJ}$, $40 \%$ does not appear to make any additional carbon saving. This can be explained by the fact that the value of tonne-km of FA40 is higher than FA30 (Table 2) due to transportation of 
additional amount of fly ash (i.e. 10\%) from coal fired power plant to the point of use. The emissions from this additional amount of tonne-km outweigh the emissions saving benefits of the substitution of additional amount of cement (i.e. 10\%) by FA40 concrete. Similarly, the value of embodied energy consumption has not been decreased with the increase of FA in concrete due to the fact that an additional amount of diesel was burnt for transporting an additional amount of FA to the point of use.

It is derived from Table 5 that carbon footprint of the use of $1 \mathrm{~m}^{3}$ of concrete in the marine environment can be decreased by $22.1 \%$ and $21.9 \%$ due to replacement of FA0 with FA30 and FA40, respectively. Similarly, embodied energy consumption can be decreased by $9.2 \%$ and 8.9\% due to replacement of FA0 with FA30 and FA40, respectively. $\mathrm{CO}_{2}$ e- saving benefit of the use of fly ash is more than that of embodied energy consumption mainly due to the avoidance of carbon intensive electricity in both cement manufacturing and batching plants. the means. This validates the quality of data used in this LCA analysis [22].

\section{Table 5}

Mean and SD of carbon footprint and embodied energy consumption

\begin{tabular}{lccccc}
\hline FA0 & & & & \\
Impact category & Unit & Mean & Median & $\mathrm{SD}$ & $\mathrm{CV}$ \\
Embodied energy consumption & $\mathrm{MJ} \mathrm{LHV}$ & 3090 & 3069 & 233 & 7.5 \\
Global warming & $\mathrm{kg} \mathrm{CO}_{2}$ e- & 345 & 344 & 13.1 & 3.8 \\
\hline FA30 & & & & & \\
Cumulative energy demand & $\mathrm{MJ} \mathrm{LHV}$ & 2807 & 2799 & 173 & 6.2 \\
Global warming & $\mathrm{kg} \mathrm{CO}_{2} \mathrm{e}-$ & 269.0 & 268.9 & 9.4 & 3.5 \\
\hline FA40 & & & & & \\
Cumulative energy demand & $\mathrm{MJ} \mathrm{LHV}^{\text {Global Warming }}$ & 2816 & 2804 & 173.14 & 6.1 \\
& $\mathrm{~kg} \mathrm{CO}_{2} \mathrm{e}-$ & 269 & 269 & 9.2 & 3.42 \\
\hline
\end{tabular}


406 The flow network of the FA40 concrete is shown in Fig. 4. Mining to material stage accounts 407 for significant portion of total environmental impacts (77\%) even with $40 \%$ substitution of 408 cement by fly ash in concrete, as shown by the red thick lines in Fig. 4. Other stages do not 409 seem to influence the overall environmental performance of concrete. Cement alone accounts 410 for $72 \%$ of the total carbon footprint of FA40 and is being considered as an environmental 411 hotspot. This is mainly because of the fact that cement is an energy intensive material and the 412 energy for cement production alone accounts for 35\% (i.e. 19\% thermal and 16\% electricity) 413 of the total carbon footprint of FA40. Therefore, the substitution of fossil fuels by renewable 414 fuels in the energy-intensive cement manufacturing process can be considered to further reduce $415 \mathrm{CO}_{2}$ emissions and to conserve energy resources for the future generations [51]. On the other 416 hand, waste combustion has been found to be well suited to cement kilns because of these fuels' 417 high process temperature and because the clinker product and limestone feedstock act as gas418 cleaning agents. Used tyres, wood, plastics, chemicals, treated municipal solid waste and other 419 types of waste can be co-combusted in cement kilns in large quantities. Cement producers in 420 Belgium, France, Germany, the Netherlands and Switzerland have reached substitution rates ranging from $35 \%$ to more than $80 \%$ of the total energy used, while in Australia, alternative 422 fuels account for only less than $10 \%$ of the total cement energy consumption [52].

423 The use of renewable energy for electricity supply and waste for cement kiln in the cement 424 production could help further reduce carbon footprint and embodied energy consumption of 425 FA40 concrete. 


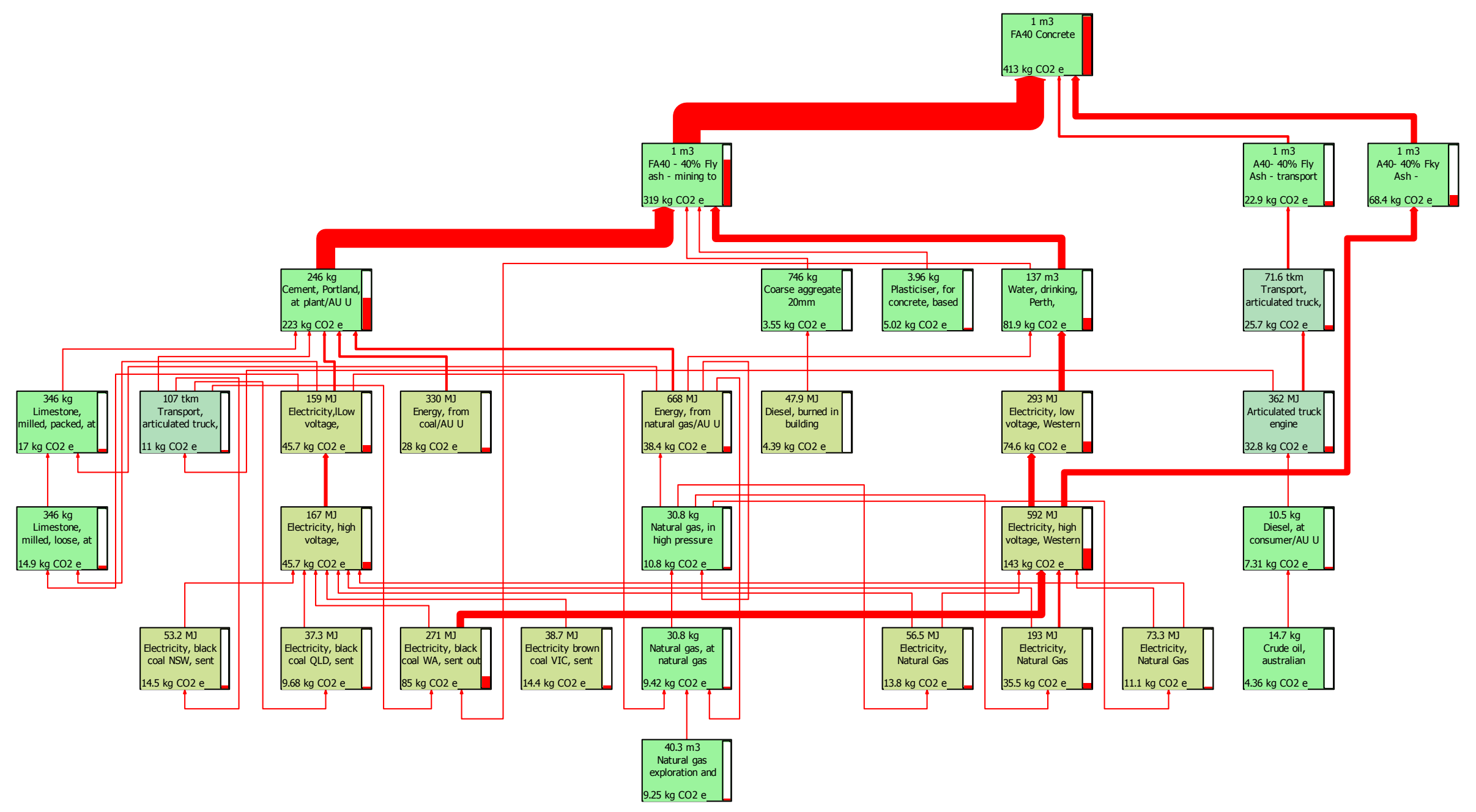

Fig 4. Flow network of FA40 concrete. 

electricity that is consumed in the final stage of milling of cement production can potentially be generated from renewable resources [53]. This milling stage alone is responsible for around half of the overall electricity that is consumed in the cement manufacturing process. In Western Australia, a significant portion of the renewable electricity (63\%) is generated from wind [54]. Therefore, electricity generation from wind turbines can be considered to supply electricity for this milling process of cement production. Following the information obtained from Lund and Biswas [55] and LCS [30], it has been estimated that 99\% of GHG emissions from the electricity generation can be avoided by substituting current Western Australian grid electricity with wind generators. The use of wind electricity could thus reduce the GHG emission by 22.6 $\mathrm{kg} \mathrm{CO}_{2}$ e- (i.e. $\left.(45.7 \mathrm{~kg}-45.7 \mathrm{~kg} \times(100-99) / 100) / 2\right)$ from the milling process of cement production. On the other hand, it was estimated that $5 \%$ of $\mathrm{CO}_{2}$ emission can potentially be mitigated by replacing $30 \%$ of coal with municipal solid waste (MSW) to meet the thermal energy demand of clinker production in Australia [56]. Fig. 4 shows that $28 \mathrm{~kg} \mathrm{CO}_{2}$ is emitted from the combustion of coal to meet the demand of thermal energy. If $30 \%$ of coal is replaced with MSW, about $1.4 \mathrm{~kg} \mathrm{CO} 2$ e- $\mathrm{GHG}$ emissions (i.e. $28 \mathrm{~kg}-(100-5) / 100 \times 28 \mathrm{~kg}$ ) can be mitigated to meet the demand for thermal energy for clinker production (Fig. 4). Therefore, it is estimated that approximately $6 \%$ (i.e. $413-22.5-1.4=389 \mathrm{~kg} \mathrm{CO}_{2}$ e) of the total carbon footprint of FA40 can be reduced due to use of these two improvement measures. consumption. Since FA30 and FA40 have the same service life (Table 3), only FA40 has been compared with FA0 concrete to investigate the impact of service life on their environmental performance. Table 6 shows the embodied energy consumption and carbon footprints of concrete mixtures in terms of per $\mathrm{m}^{3}$ per year basis for different concrete covers (i.e. $35 \mathrm{~mm}$, 
between $35 \mathrm{~mm}$ and $50 \mathrm{~mm}$, carbon footprint saving (36\% - 43\%) and embodied energy

454

455

456

457

458

459

460

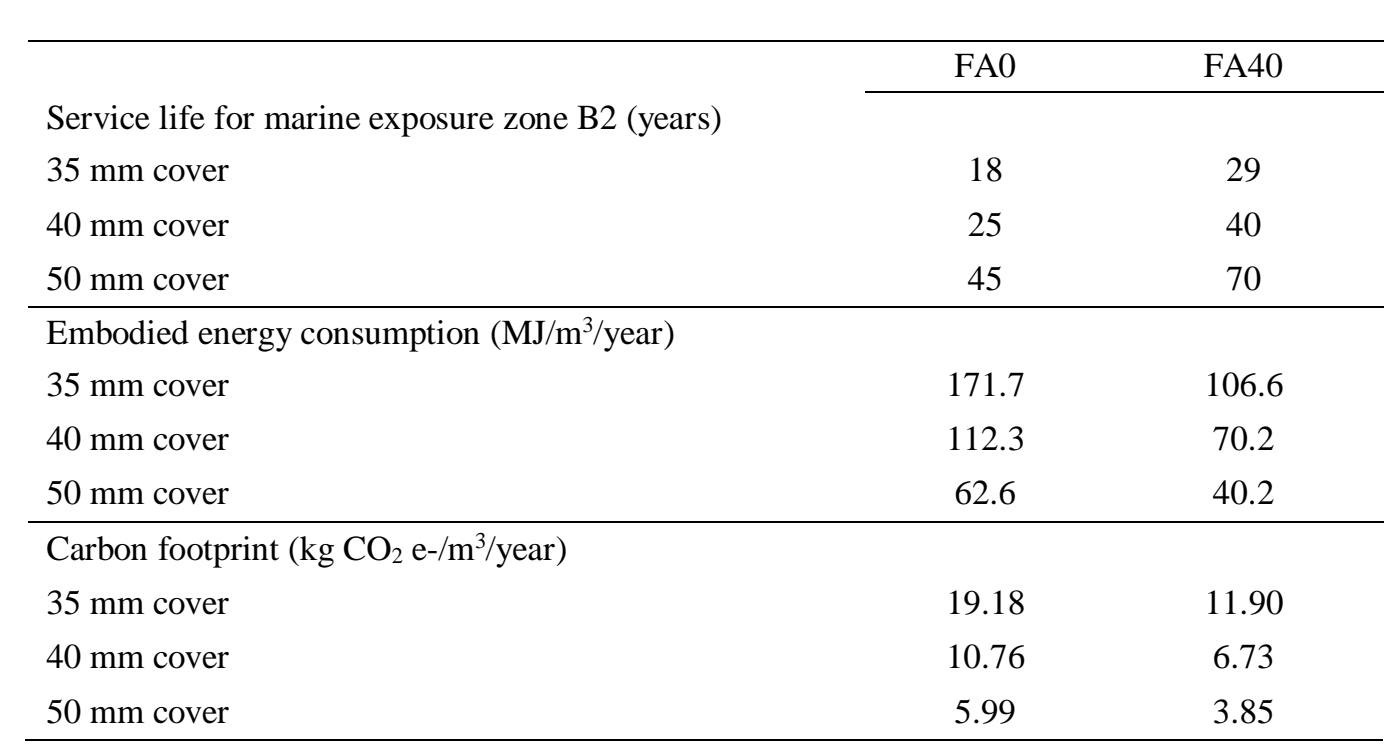

consumption saving $(36 \%-38 \%)$ have emerged as significant benefits of the use of FA in

concrete. The carbon footprint and embodied energy consumption have been found to decrease with the increase of thickness of concrete covers.

\section{Table 6}

Effect of service life on the embodied energy consumption and carbon footprint of concrete mixtures
461

462

463

464

465

466

467

\section{Conclusions}

Use of fly ash as a partial replacement of cement in concrete for marine infrastructure (e.g. seaport buildings, desalination plant) has not only been found structurally sound but also offers significant environmental benefits in terms of increased durability, reduction of carbon intensive cement production and conversion of waste to resources. The substitution of $40 \%$ cement with fly ash in concrete (i.e. FA40) has been found to increase the service life by 1.6 to 1.75 times more than the conventional concrete (FA0) for the covers to reinforcing steel 
between $35 \mathrm{~mm}$ and $50 \mathrm{~mm}$, when used in the aggressive marine environment. This increased durability of fly ash concrete conserves raw materials and energy for cement production and also reduces associated GHG emissions and embodied energy consumption.

Life cycle assessment analysis has been conducted to capture the carbon footprint and embodied energy consumption saving benefits associated with use of FA as partial replacement of cement in concrete. The replacement of FA0 with FA30 and FA40 could potentially reduce the carbon footprint by $22.1 \%$ and $21.9 \%$ per $\mathrm{m}^{3}$ of concrete, respectively and embodied energy consumption by $9.2 \%$ and $8.9 \%$, respectively. Cement accounting for $72 \%$ of the total carbon footprint of FA40 concrete, has thus been identified as the hotspot even after $40 \%$ replacement of cement with fly ash. The carbon footprint of this FA40 concrete can be reduced further by $24 \%$ by using renewable energy sources such as wind and MSW in the milling and clinker production processes in the cement manufacturing plant.

Last but not the least, service life has a significant bearing on the overall environmental performance of concrete mixtures. When FA40 is compared with FA0 per $\mathrm{m}^{3}$ per year basis, the former has been found to save carbon footprints between $36 \%$ - 43\% and embodied energy consumption between $36 \%$ - 38\% for different concrete covers to reinforcing steel between 35 $\mathrm{mm}$ and $50 \mathrm{~mm}$. The other indirect environmental benefits that could result in due to use of this fly ash in concrete in the aggressive marine environment are the reduction of land use changes and loss of biodiversity associated with the production of cement and disposal of fly ash at the coal fired power plants. Provided there is a long term continuing supply of fly ash by-product from a variety of sources, concrete mixtures of FA30 and FA40 could help achieve a sustainable infrastructure for Australia. 
494 production of cement from limestones. On the other hand, the coal power plant will benefit 495 from the reduction of residue handling area, as well as, health effects associated with the 496 presence of FA in air.

497

498 
1. E. Benhelala, G. Zahedia, E. Shamsaeib, A. Bahadoric, Global strategies and potentials to curb CO2 emissions in cement industry, Journal of Cleaner Production, 51 (2013) $142-161$.

2. $\mathrm{CO}_{2}$ and Climate Protection http://www.wbcsdcement.org/index.php/key-issues/climateprotection

3. Global cement production from 1990 to 2030 https://www.statista.com/statistics/373845/global-cement-production-forecast/

4. J. I. Escalante-Garcia, J. H. Sharp, The chemical composition and microstructure of hydration products in blended cements. Cement and Concrete Composites, 26 (2004) 967-976.

5. R. Siddique, Performance characteristics of high-volume Class F fly ash concrete. Cement and Concrete Research, 34 (2004) 487-493.

6. Ash Development Association of Australia (2015) Annual Membership Survey Results, http://www.adaa.asn.au/uploads/default/files/adaa_mship_report_20162.pdf

7. Types and Causes of Concrete Deterioration, Portland Cement Association. http://www.cement.org/docs/default-source/fc_concrete_technology/durability/is536types-and-causes-of-concrete-deterioration.pdf?sfvrsn=4

8. P. K. Mehta, (1990). Causes of Deterioration of Concrete in Seawater. Concrete in the Marine Environment. Routledge. Retrieved from http://www.crcnetbase.com.dbgw.lis.curtin.edu.au/ISBN/9780203498255

9. Strategic Development Council (SDC). (2006), Vision 2020- A Vision for the Concrete Repair, Protection and Strengthening Industry. Retrieved from http://www.concretesdc.org/_pdfs/Vision2020-Version1.0_\%20May2006.pdf (accessed July 1, 2017). 
10. A. Camoes, B. Aguiar, S. Jalali, (2003) Durability of low cost high performance fly ash concrete. 2003 International Ash Utilization Symposium, Centre for Applied Energy Research, University of Kentuky.

11. M. D. A. Thomas, J. D. Matthews, Performance of pfa concrete in a marine environment10-year results, Cement and Concrete Composites, 26(2004) 5-20.

12. A. Bilodeau, V. M. Malhotra, High-volume fly ash system: concrete solution for sustainable development. ACI Materials Journal, 97(1)(2000), 41-50.

13. W. Chalee, P. Ausapanit, C. Jaturapitakkul, Utilization of fly ash concrete in marine environment for long term design life analysis, Materials and Design 31 (2010) 12421249.

14. T. Cheewaket a, C. Jaturapitakkul a, W. Chalee, Long term performance of chloride binding capacity in fly ash concrete in a marine environment, Construction and Building Materials, 24 (2010) 1352-1357

15. T. Cheewaket, C. Jaturapitakkul, W. Chalee, Concrete durability presented by acceptable chloride level and chloride diffusion coefficient in concrete: 10-year results in marine site, Materials and Structures 47 (2014) 1501-1511

16. C. S. Poon, L. Lam, Y. L. Wong, A study on high strength concrete prepared with large volumes low calcium fly ash. Cement and Concrete Research, 30 (2000) 447-455.

17. ASBEC (2007) Capitalising on the Building Sector's Potential to Lessen the Costs of a Broad Based GGHG Emissions Cut, Centre for International Economics, Canberra.

18. ABCB (2015) NCC Volume Two - Energy Efficiency Provisions $-3^{\text {rd }}$ Edition. Australian Building Codes Board (ABCB), Canberra.

19. Tom Arup PH (2015) Paris UN Climate Conference 2015: Tackling warming 'inspires us', Turnbull tells summit. Sydney, Australia 
20. K. Lawania, W.K. Biswas, Application of life cycle assessment approach to deliver low carbon houses at regional level in Western Australia, The International Journal of Life Cycle Assessment, (2017), published online.

21. ISO14040 (2006) ISO 14040:2006 - Environmental Management -- Life Cycle Assessment -- Principles and Framework, International Organization for Standardization, Geneva.

22. W.K. Biswas, Carbon footprint and embodied energy consumption assessment of building construction works in Western Australia, International Journal of Sustainable Built Environment 3 (2) (2014) 179-186.

23. J. Monahan, J.C. Powell, An embodied carbon and energy analysis of modern methods of construction in housing: a case study using a lifecycle assessment framework, Energy and Buildings 43 (1) ( 2011) 179-188.

24. Standards Australia, Portland and blended cements (AS 3972), 1997.

25. ASTM Standards, Standard Specification for Coal Fly Ash and Raw or Calcined Natural Pozzolan for Use in Concrete (ASTM C 618 - 08a), 2008.

26. Standards Australia, Aggregates and rock for engineering purposes Part 1: Concrete aggregates (AS 2758.1-1998), 1998.

27. American Concrete Institute, Guide for selecting proportions for high-strength concrete using Portland cement and other cementitious materials (ACI 211.4R-08)", ACI Committee 211, 2008, MI, USA.

28. Nordtest Method, Concrete, Hardened: Accelerated Chloride penetration (NT Build 443, 1995-11), 1995.

29. A. Fick, On liquid diffusion, Journal of Membrane Science, 100(1) (1995) 33-38

30. H. T. Cao, L. Bucea, Guidelines for the Use of Fly Ash Concrete in Marine Environments, CSIRO Research Report BRE 062, 2000. 
573 31. K.A. Riding, Early age concrete thermal stress measurement and modelling, $\mathrm{PhD}$ Thesis, 574 The University of Texas at Austin, 2007.

575

576

577

578

579

580

581

582

583

584

585

586

587

588

589

590

591

592

593

594

595

596

32. M. D. A. Thomas, A. Scott, Bremner, T., A. Bilodeau, D. Day, Performance of slag concrete in marine environment, ACI Materials Journal, 105 (6) (2008) 628-634.

33. R. P Khatri, V. Sirivivatnanon, Characteristic service life for concrete exposed to marine environments, Cement and Concrete Research, 34 (2004) 745-752.

34. Pré Consultants (2016) SimaPro database. Pré Consultants, The Netherlands.

35. Life Cycle Strategies Pty Ltd. (2015). Australasian Unit Process LCI Library and Methods. Version 2015_02_06. http://www.lifecycles.com.au/\#!australasian-database/cbm5.

\section{Accessed 30 Jun 2015.}

36. A Hans-Jorg Ecoinvent Unit Processes for SimaPro. (2010) Switzerland

37. IPCC (Intergovernment Panel on Climate Change) (2007) Direct Global Warming Potentials, IPCC Switzerland https://www.ipcc.ch/publications_and_data/ar4/wg1/en/ch2s2-10-2.html

38. UNFCCC. (1992). United Nations framework convention on climate change. Germany: United Nations Framework Convention on Climate Change.

39. P. M. Fearnside, Why a 100-year time horizon should be used for global warming mitigation calculations. Mitigation and Adaptation Strategies for Global Change, 7(2002). 19-30.

40. Y.A. Fatimah, W.K. Biswas, Remanufacturing as a means for achieving low-carbon SMEs in Indonesia, Clean Technologies and Environmental Policy, 18(8) (2016) 2363-2379.

41. J. Clavreul, D. Guyonnet, T Christensen, Quantifying uncertainty in LCA-modelling of waste management systems. J Waste Manage, 32 (2012) 2482-2495.

42. M. Goedkoop, M. Oele, J. Leijting, T. Ponsioen, E. Meijer (2013) Introduction to LCA with SimaPro. PRé, Netherlands.

43. Standards Australia, "Concrete Structures (AS 3600-2009)”, 2009. 
44. B. Marsh, R. Day, Pozzolanic and cementitious reactions of fly ash in blended cement pastes. Cement and Concrete Research, 18(2) (1988) 301-310.

45. P. Nath, P. Sarker, Effect of mixture proportions on the drying shrinkage and permeation properties of high strength concrete using class F fly ash. KSCE Journal of Civil Engineering (2013) 17(6) (2013) 1437-1445.

46. Song, H. W., Lee, C. H., \& Ann, K. Y., "Factors influencing chloride transport in concrete structures exposed to marine environments", Cement \& Concrete Composites, 30, 2008, pp 113-121.

47. M.D.A. Thomas, Author's reply to discussion of paper chloride thresholds in marine concrete. Cement and Concrete Research, 26 (1996) 1603-4.

48. N. Shafiq, Effects of fly ash on chloride migration in concrete and calculation of cover depth required against the corrosion of embedded steel reinforcement. Structural Concrete, 5, (2004) 5-9.

49. M. Thomas, "Chloride thresholds in marine concrete", Cement and Concrete Research, 26 (4), 1996, pp 513-520.

50. Green Star: The what and why of certification, http://new.gbca.org.au/green-star/

51. Lafargeholcim (2017) Solar energy in cement manufacturing, LafargeHolcim Ltd. Zürcherstrasse 1568645 Jona, Switzerland.

52. UNIDO (2010) United Nations Industrial Development Organization) Renewable Energy in Industrial Applications - An assessment of the 2050 potential, UNIDO, Vienna, Austria

53. Australian Government (2015) Renewable Energy (Electricity) Amendment (Production of 618 Clinker) Regulation 2015. Department of the Environment and Energy, Australian 9 Government, Parkes ACT 2600 Canberra.

54. WWA, (2011) Wind WA, http://ramblingsdc.net/Australia/WindWA.html. 
621 55. C. Lund, W.K. Biswas, A review of the application of lifecycle analysis to renewable energy

622 systems, Bulletin of Science, Technology \& Society, 28 (2008) 200-209.

623 56. A. Rahman, Utilization of waste products as alternative fuels for cement industry, $\mathrm{PhD}$ 624 Thesis, Central Queensland University, School of Engineering and Technology, North 625 Rockhampton QLD 4702, Australia, 2016.

626

627

628

629

630

631

632

633 